\title{
PENGARUH PENDEKATAN OPEN-ENDED TERHADAP KEMAMPUAN BERPIKIR KREATIF MATEMATIS SISWA DI SMA ANTARTIKA SIIDOARJO
}

\author{
Ainur Rosita ${ }^{1}$, Erlin Ladyawati ${ }^{2}$ \\ (SMA Kartika Sidoarjo) ${ }^{1}$

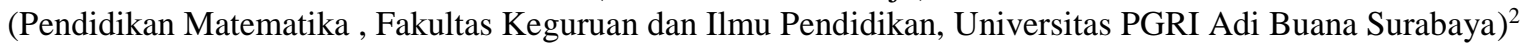 \\ shita7109@gmail.com ${ }^{1}$, erlin.evaluasi@gmail.com²
}

\begin{abstract}
This research supported by time progress more advanced. Where future need people who have high levels of creativity. That is why students for the foreseeable future must be more sharpening the capacity to think creative. But the important role of teacher, no less important that approach learning held at the time. To make students creative thinking, students are faced with the problem open-ended goals not oriented in the final answer but more emphasis on the process of to get answers. The formulation of the research is "can influence open-ended approach of the ability of creative thinking mathematically students?" the purpose of this research is to know how big the influence of open-ended approach of the ability of creative thinking mathematically students". In this research to measures the creative thinking mathematically students do with the tests the ability of creative thinking that leads to the creative thinking that: mathematical that: elaboration , flexibility, the problem sensitivity, originality, and fluency. The population in this research is the students of SMA Antartika Sidoarjowith the sample class XI MIPA 3 as a class experiment and XI MIPA 4 as a control class. Research data obtained analyzed using normality test, homogeneity test and t-test. Ho hypothesis research: no influence open-ended approach with conventional lessons in the ability of creative thinking mathematically students in SMA AntartikaSidoarjo academic year 2015-2016, while $\mathrm{H}_{1}$ : there is the influence of open-ended approach with conventional lessons in the ability of creative thinking mathematically students in SMA AntartikaSidoarjo academic year 2015-2016. its testing criteria that its $\mathrm{t}_{\text {arithmetic }}<\mathrm{t}_{\text {table. }}$ Of calculation $\mathrm{t}$-test obtained 2,594>1.98932, Ho rejected it means. So that in this study concluded that there is influence open-ended approach towards the ability of creative thinking mathematically students in SMA AntartikaSidoarjo academic year 2015-2016.
\end{abstract}

Keywords: Open-ended approach,creative thinking mathematical.

\section{PENDAHULUAN}

Dewasa ini perkembangan zaman semakin maju.berbeda dengan era sebelumnya, pada era informasi ini perubahan terjadi setiap detik (Usman, ed., 2013:47). Beberapa bidang yang mengalami kemajuan pesat antara lain: teknologi, informasi, transportasi, pariwisata, Fashion, industri dll. Berdasarkan penelitian bank Dunia terhadap 150 negara diketahui bahwa faktor-faktor penentu kemajuan suatu Negara secara berurutan sesuai dengan besarnya pengaruh adalah: inovasi dan kreativitas (45\%), Jaringan kerja sama (25\%), teknologi (20\%), dan sumber daya alam hanya $10 \%$ sukmadinata (dalam usman, ed., 2013:49). Terlihat jelas bahwa kreativitas menempati presentase yang paling besar, artinya setiap negara membutuhkan orang orang yang kreatif.
Mengingat tuntutan era globalisasi saat ini, diharapkan generasi muda penerus bangsa memiliki kemampuan berpikir kreatif agar dapat hidup fungsional dan bermakna. Peran guru sangatlah penting untuk membantu siswa agar siswa dapat mengasah kemampuan berfikir kreatifnya dan bisa memecahkan masalah untuk dapat bersaing, karena persaingan di era globalisasi seperti sekarang ini sangat ketat. Selain pentingnya peran guru, tidak kalah penting yaitu pendekatan pada saat pembelajaran berlangsung. Untuk membuat siswa berpikir kreatif, siswa dihadapkan dengan problem Open-Endedtujuan utamanya bukan berorientasi pada jawaban akhir tetapi lebih menekankan pada cara atau proses dalam memperoleh jawaban.

Pembelajaran dengan pendekatan Open-Ended problem biasanya dimulai dengan memberikan problem terbuka pada siswa. Kegiatan pembelajaran harus 
membawa siswa dalam menjawab permasalahan dengan banyak cara dan mungkin juga banyak jawaban yang benar sehingga mengundang potensi intelektual dan pengalaman siswa dalam proses menemukan sesuatu yang baru.

Peneliti menjumpai pada tempat penelitian yakni masih banyak para siswa khususnya pada saat pembelajaran matematika menganggap bahwa matematika hanya dapat diselesaikan dengan satu cara dan hanya mendapatkan satu hasil (one problem- one solution) atau dapat dikatakan seragam. Sebagai pendidik kita harus berusaha membantu para siswa agar dapat mengembangkan kemampuan berpikir kreatifnya agar dapat menyelesaikan persoalan dengan berbagai cara dan berbagai macam jawaban.

Terkait dengan latar belakang tersebut, penulis meneliti tentang "Pengaruh pendekatan Open-Ended terhadap kemampuan berpikir kreatif matematis siswa di SMA Antartika Sidoarjo tahun ajaran 2015-2016.”

Berdasarkan latar belakang di atas, rumusan masalah penelitian ini adalah, Adakah pengaruh pendekatan OpenEnded terhadap kemampuan berpikir kreatif matematis siswa di SMA Antartika Sidoarjo tahun ajaran 2015-2016? yang hasilnya diharapkan dapat bermanfaat khususnya untuk guru agar dapat mengembangkan kemampuan berpikir kreatif matematis siswa. Dengan demikian penelitian ini bertujuan untuk mengetahui ada tidaknya pengaruh pendekatan Open-ended terhadap kemampuan berpikir kreatif matematis siswa di SMA Antartika Sidoarjo tahun ajaran 2015-2016.

\section{METODE PENELITIAN}

Penelitian ini merupakan penelitian kuantitatif. Adapun rancangan penelitian yang peneliti lakukan adalah menetukan subyek penelitian, menentukan kelompok eksperimen dan kelompok kontrol, menerapkan pendekatan Open-Ended pada kelompok eksperimen dan model pembelajaran konvensional pada kelompok kontrol, memberikan tes yang sama pada kedua kelompok pada akhir pembelajaran.

Pengambilan sampel penelitian dilakukan dengan cara acak (Random sampling) didapat kelas XI MIPA 3 sebagai kelas eksperimen dan XI MIPA 4 sebagai kelas kontrol. Teknik pengumpulan data menggunakan tes. Tes dalam penelitian ini adalah soal tes kemampuan berpikir matematis berbentuk uraian terdiri dari 5 soal. Langkah pengumpulan data penelitian dilakukan dengan cara mengerjakan soal tes hasil belajar matematika materi hubungan antar garis yang telah divalidasi ke guru pelajaran matematika dan dosen matematika. Data hasil penelitian dianalisis dengan menggunakan uji-t, tetapi sebelum menggunakan uji-t peneliti terlebih dahulu menguji kenormalan dan kehomogenan data dengan menggunakan uji normalitas dan uji homogenitas.

a. Uji Normalitas

Mencari standar deviasi (s) dengan rumus:

$$
s^{2}=\sqrt{\frac{n \sum f_{0} \cdot x_{i}^{2}-\left(\sum f_{0} \cdot x_{i}\right)^{2}}{n(n-1)}}
$$

Menghitung $x^{2}$ hitung dengan rumus :

$$
x_{\text {hitung }}=\sum_{i=1}^{k} \frac{f_{0}-f_{h}}{f_{h}}
$$

b. Uji Homogenitas

Mencari $F_{\text {hitung }}$ dengan menggunakan rumus:

$$
F=\frac{\text { varian terbesar }}{\text { varian terkecil }}
$$

c. Uji-t

Mencari $t_{\text {hitung }}$ dengan rumus:

$t=\frac{\bar{x}_{1}-\bar{x}_{2}}{\sqrt{\frac{\left(n_{1}-1\right) \mathrm{s}_{1}^{2}+\left(\mathrm{n}_{2}-1\right) \mathrm{s}_{2}^{2}}{n_{1}+n_{2}^{-2}}}\left(\frac{1}{n_{1}}+\frac{1}{n_{2}}\right)}$

Dengan

$s^{2}=\sqrt{\frac{n \sum f_{0} \cdot x_{i}^{2}-\left(\sum f_{0} \cdot x_{i}\right)^{2}}{n(n-1)}}$

Uji normalitas data menggunakan rumus chi-kuadrat, kemudian pengujian homogenitas menggunakan uji-f.

\section{HASIL PENELITIAN}


Hasil penelitian ini dipaparkan dalam dua sajian. Sajian pertama adalah deskripsi data dan sajian kedua adalah pengujian hipotesis data.

Deskripsi data. Dalam penelitian ini persiapan penelitian yang dilakukan peneliti antara lain memilih masalah yang akan diteliti, merumuskan masalah, memilih model pembelajaran yang akan dibandingkan, menentukan variabel, menentukan populasi dan sampel, membuat perangkat pembelajaran serta menyusun instrumen berupa soal uraian tes hasil belajar yang akan diberikan di kelas eksperimen dan kelas kontrol. Jadwal penelitian dilaksanakan masing-masing tiga kali pertemuan di kelas eksperimen dan kelas kontrol.

Pengujian hipotesis. Data yang telah diperoleh diolah dengan menggunakan metode statistika yaitu analisis ujit. Sebelum melakukan uji-t maka terlebih dahulu harus dilakukan uji normalitas dan homogenitas data dengan maksud untuk mengetahui apakah data tersebut berdistribusi normal dan homogen. Uji normalitas menggunakan uji chi-kuadrat dan setelah dihitung di kelas eksperimen $x_{\text {hitung }}^{2}=5.57, x_{\text {tabel }}^{2}=11.07$, maka data berdistribusi normal, sedangkan kelas kontrol $x_{\text {hitung }}^{2}=7.71, x_{\text {tabel }}^{2}=11.07$, maka data berdistribusi normal. Setelah diketahui data berdistribusi normal kemudian dilakukan pengujian homogenitas data menggunakan uji $\mathrm{f}$, diperoleh nilai $\mathrm{F}_{\text {hitung }}=1.08$, $\mathrm{F}_{\text {tabel }}=5.05, \mathrm{~F}_{\text {hitung }} \leq F_{\text {tabel }}$ maka varians data tersebut homogen. Setelah data dinyatakan normal dan homogen maka langkah selanjutnya adalah menguji hipotesis dengan menggunakan uji t. Hipotesis dalam penelitian ini adalah Tidak ada pengaruh pendekatan Open-ended dengan pembelajaran konvensional terhadap kemampuan berpikir kreatif matematis siswa di SMA Antartika Sidoarjo tahun ajaran 2015-2016 $\left(H_{0}\right)$, dan ada pengaruh pendekatan Open-ended dengan pembelajaran konvensional terhadap kemampuan berpikir kreatif matematis siswa di SMA Antartika Sidoarjo tahun ajaran 2015-2016 $\left(H_{1}\right)$. Dengan taraf signifikan yaitu 5\% $\alpha=0.05$ serta menghitung $d k$ dengan rumus $d k=n_{1}+n_{2}-2$ didapat nilai $t_{\text {hitung }}>t_{\text {tabel }}$, maka $H_{0}$ ditolak dan $H_{1}$ diterima, hal ini berarti ada pengaruh pendekatan Open-ended dengan pembelajaran konvensional terhadap kemampuan berpikir kreatif matematis siswa di SMA Antartika Sidoarjo tahun ajaran 2015-2016.

\section{PEMBAHASAN}

Ada beberapa tahap yang harus dilakukan sebelum penelitian dilakukan, yaitu memilih dua sampel secara acak untuk dijadikan kelas eksperimen dan kelas kontrol.Penulis menyiapkan terlebih dahulu instrument soal yang berupa tes. Tes terdiri dari lima soal uraian yang mengacu pada indikator berpikir kreatif yang dikemukakan oleh Guilford (dalam herdian: 2010) dan soal tersebut di validasi terlebih dahulu oleh dosen matematika dan guru matematika. Setelah menentukan sampel, kedua kelas tersebut akan diberikan pre-test untuk mengetahui kemampuan awal. Setelah mengetahui kemampuan awal kedua kelas, peneliti memberikan treatment yang berupa pendekatan Open-Ended untuk kelas eksperimen, dan pembelajaran konvensional untuk kelas kontrol. Setelah diberikan treatment, penulis memberikan post-test untuk mengetahui adakah perbedaan kemampuan berpikir kreatif matematis siswa pada kedua kelas tersebut.

Selanjutnya selisih hasil pre-test dan post-test kelas eksperimen dan kelas kontrol akan diuji hipotesis penelitiannya dengan menggunakan uji-t. Sebelum masuk pada tahap uji-t, penulis terlebih dahulu melakukan uji normalitas untuk mengetahui apakah data berdistribusi normal. Ternyata pada kelas eksperimen didapatkan hasil $5,56520818<11,07$ atau $x^{2}{ }_{\text {hitung }}<x^{2}$ tabel dan pada kelas kontrol $7,1078131<11,07$ atau $x_{\text {hitung }}^{2}<x^{2}$ tabel yang artinya data berdistribusi normal.

Setelah kedua data berdistribusi normal, selanjutnya akan dilakukan uji homogenitas, tujuannya untuk mengetahui apakah kedua data bersifat homogen. Didapati 
hasilnya adalah $\mathrm{F}_{\text {hitung }}<\mathrm{F}_{\text {tabel }}=1,0819407<5,05$. Dengan demikian berarti data hasil belajar siswa bersifat homogen.

Tahap terakhir yaitu uji T. uji T dilakukan jika kedua data dinyatakan berdistribusi normal dan homogen. Didapatkan bahwa $t_{\text {hitung }}<t_{\text {tabel }}=2,594<1,98932$ Artinya Ho ditolak, maka dapat dinyatakan bahwa Ada pengaruh pendekatan Open-Ended terhadap kemampuan berpikir kreatif matematis siswa di SMA Antartika Sidoarjo tahun ajaran 2015-2016.

\section{PENUTUP}

\section{Simpulan}

Berdasarkan penelitian di atas, dapat diperoleh bahwa terdapat perbedaan kemampuan berpikir kreatif siswa yang pembelajarannya menggunakan pendekatan Open-Ended dengan model pembelajaran konvensional. Siswa yang pembelajarannya menggunakan pendekatan Open-Ended memiliki rata-rata dari hasil tes berpikir kreatif lebih tinggi dari pada model pembelajaran konvensional.Maka penulis dapat menyimpulkan bahwa terdapat pengaruh pendekatan Open-Ended terhadap kemampuan berpikir kreatif matematis siswa di SMA Antartika Sidoarjo tahun ajaran 2015-2016

\section{Saran}

Dalam penelitian ini, ada beberapa saran penulis terkait penelitian ini, diantaranya:

1) Bagi siswa

Siswa sebaiknya lebih percaya diri saat mengemukakan jawaban.

2) Bagi Guru
Pembelajaran matematika dengan pendekatan Openended mampu meningkatkan kemampuan berpikir kreatif matematis siswa, sehingga pembelajaran tersebut dapat menjadi salah satu variasi pembelajaran matematika yang dapat diterapkan.

\section{3) Bagi Sekolah}

Pihak sekolah dapat memotivasi guru untuk selalu mencoba pendekatan pembelajaran yang lain, agar kemampuan berpikir kreatif siswa dapat lebih berkembang.

\section{DAFTAR PUSTAKA}

Arikunto, S. 2010. Prosedur Penelitian (Edisi Revisi). Jakarta: Penerbit Rineka cipta.

Rochmanto, Wahyu Priyogo.2014. pengaruh pendekatan open ended terhadap kemampuan berpikir kreatif matematis siswa. Skripsi. Jakarta: fakultas ilmu tarbiyah dan keguruan, uin syarif hidayatullah.

Sudjana. 2005. Metoda Statistika. Bandung: Penerbit Tarsito.

Sugiyono. 2014. Metode Penelitian Pendidikan pendekatan Kuantitatif, Kualitatif dan $R \& D$. Bandung: Alfabeta.

Sunito, dkk. 2013. Metaphorming. Jakarta: Penerbit PT Index.

Herdian. 2010. Kemampuan Berfikir Kreatif Siswa. Tersedia pada (https://herdy07.wordpress.com/2010/05/27/kemampu an-berfikir-kreatif-siswa/). Diakses pada tanggal 18 Agustus 2015. 